\title{
British Neolithic Axehead Distributions and Their Implications
}

\section{Peter Schauer ${ }^{1}$ - Andrew Bevan ${ }^{1} \cdot$ Stephen Shennan ${ }^{1}$ (D) Kevan Edinborough $^{2}$. Tim Kerig ${ }^{3} \cdot$ Mike Parker Pearson $^{1}$}

Published online: 20 December 2019

(C) The Author(s) 2019, corrected publication 2020

\begin{abstract}
Neolithic stone axeheads from Britain provide an unusually rich, well-provenanced set of evidence with which to consider patterns of prehistoric production and exchange. It is no surprise then that these objects have often been subject to spatial analysis in terms of the relationship between particular stone source areas and the distribution of axeheads made from those stones. At stake in such analysis are important interpretative issues to do with how we view the role of material value, supply, exchange, and demand in prehistoric societies. This paper returns to some of these well-established debates in the light of accumulating British Neolithic evidence and via the greater analytical power and flexibility afforded by recent computational methods. Our analyses make a case that spatial distributions of prehistoric axeheads cannot be explained merely as the result of uneven resource availability in the landscape, but instead reflect the active favouring of particular sources over known alternatives. Above and beyond these patterns, we also demonstrate that more populated parts of Early Neolithic Britain were an increased pull factor affecting the longer-range distribution of these objects.
\end{abstract}

Keywords Neolithic $\cdot$ Britain $\cdot$ Radiocarbon $\cdot$ Stone axeheads $\cdot$ Spatial analysis $\cdot$ Cluster analysis

\section{Introduction}

Prehistoric edge-ground stone tools are a key form of human material culture, found across a vast range of cultural settings and interpreted with more or less regard to their potential roles as socially charged emblems, proto-currencies, and/or functional tools. Spatial distributions of stone axeheads have been a particular focus of study, not least as

Electronic supplementary material The online version of this article (https://oi.org/10.1007/s10816-01909438-6) contains supplementary material, which is available to authorized users.

Stephen Shennan

s.shennan@ucl.ac.uk

Extended author information available on the last page of the article 
part of intensive efforts to understand prehistoric exchange mechanisms (e.g. Hodder 1974; Renfrew 1975, 1977; and see discussion below). A striking, early, and large-scale example of an ultra-long distance spread of stone axeheads from a single source region is provided by European Neolithic axeheads of Alpine rocks, including jadeitite, omphacite, and eclogite (Pétrequin and Pétrequin 2012). These visually distinctive, elaborately produced, onerously accessed, carefully curated axeheads were made from south-western Alpine sources, but ended up deposited in contexts across large swathes of western Europe, sometimes over a thousand kilometres away. Indeed, Alpine axeheads may well have played a culturally foundational role in promoting an ideology of virtuoso stone extraction and axehead production that led to many more localised but analogous industries across western Europe that reached their height during the late 5th and early 4th millennia BC (Schauer et al. 2019).

Within this episode of peak western European production, the stone axeheads of Early Neolithic Britain constitute perhaps the largest and most systematic published evidence to hand. Over the last 90 years, British stone axehead studies have been pushed forward particularly effectively by the Implement Petrology Group (IPG) and its predecessors, with important ongoing efforts to link specific axeheads to specific geological sources (especially Clough and Cummins 1979, 1988). Careful characterisation by petrological thin-section analysis and optical microscopy has allowed large numbers of axeheads to be assigned to broadly agreed petrological groups (e.g. group I greenstones from Cornwall or group VI epidotised tuffs from Cumbria; see Clough and Cummins 1988: Table 3 for a full list). Such work is of course "never likely to be complete" (Grimes 1979, p. 3) given the quantity of finds and the diversity of local geology, and Pitts (1996) has suggested that more general grouping of axeheads by broad material type might be preferable. Even so, the idea that the IPG groups do represent real sets of axeheads with a common origin has been strengthened through isotopic and geochemical studies (e.g. Markham and Floyd 1998; Davis et al. 2009). The IPG's list remains too useful for addressing large-scale distribution patterns to be ignored and indeed has already benefited from a range of spatial analytical work (e.g. Darvill 1989).

A key question for many of the researchers that have so far considered British and other European stone axehead finds has been to understand what production, consumption, and exchange mechanisms might have led to the spatial distribution of axeheads that we see in the archaeological record today. Some axeheads clearly were moved long distances, including crossings by sea in the case of mainland British findspots of axeheads from Ireland and the Alps (Cooney et al. 2013; Pétrequin and Pétrequin 2012), while it remains clear that many axeheads were local regional products (Darvill 1989; Pitts 1996). Cummins (1979) recognised that axeheads of particular materials are typically found close to their source and decline in frequency with increasing distance, although occasionally secondary concentrations might appear further away. He suggested a range of mechanisms for their dispersal, from gift exchange to itinerant Neolithic traders ("pedlars" or Neolithic "salesmen", 1979, p. 7) and the role of secondary distribution centres. Darvill (1989) also suggested that a range of exchange mechanisms might have been responsible for the circulation of axeheads, but in addition highlighted the possible role of direct visits by axe users to the source regions, and seasonal migration by axe-using communities. Pitts (1996), however, pointed out that perhaps the different mechanical properties of different stones (e.g. flint might be 
more prone to breakage than igneous stones) might affect how far they travelled from their source before disposal or final deposition. Bradley and Edmonds (1993) extensively critiqued Cummins' trader and secondary-centre models, while a survey of the circulation of axeheads in the western Mediterranean (Risch 2011) likewise found no evidence of specialisation or centralisation in the axehead trade. Earthwork surveys at flint mines (Barber et al. 1999) have furthermore suggested that, despite the large number of resulting axehead products, the scale of extraction at such mines was not large in any modern industrial sense, and that prominent or exotic locations might sometimes have been favoured over more accessible or even better quality local sources (Topping 2019; see also Taylor 2017 for the role of topography at the Langdale source).

A further key question implicit or explicit in past work has been the following: to what extent was there competition amongst alternative axehead-producing communities? Indeed, given that ethnographies of twentieth century CE New Guinea (Burton 1989; Pétrequin and Pétrequin 1993) document dedicated axehead-making communities or tribes whose scale of production sometimes responded to changes in wider regional demand, to what extent was the presence of a large local pool of potential axe users in the Neolithic a good explanation for the observable density or diversity of Neolithic axehead finds? This paper returns to such debates in the light both of accumulating evidence and the much greater analytical flexibility now offered by computational methods. We first look to control more formally for research biases in such find distributions, before addressing what the geographical pattern of axeheads from known sources can reveal both individually and collectively about exchange mechanisms, and about the relationship between axeheads and British Early Neolithic regional population densities. Other things being equal, we would expect larger numbers of axes to be used and discarded in areas with higher populations. Another possibility discussed in the literature (e.g. Smith 1971) is that axeheads from longdistance sources are more frequent around causewayed enclosures because these were places where people gathered from a wide area; hence, we go on to examine the relationship between the numbers of exotic axeheads and the distribution of enclosures. Finally, in the light of arguments for two if not three distinct streams of Neolithisation in Britain, an eastern one and one or more in the west (Sheridan 2010), and for the existence of distinct spatial style zones in the pottery (Pioffet 2014), we can ask whether these divisions are in any way reflected in the axehead distributions.

\section{Materials}

Our study uses several sources of information on the spatial distribution of axeheads, primarily from the IPG (Clough and McK 1988) and Neolithic Axehead Archive (Pitts 1996), but also further relevant finds from England, Wales, and southern Scotland that have been brought together or recorded in more standardised ways by the Irish Stone Axe Project (ISAP, Cooney and Mandal 1998) and Projet JADE (Sheridan and Pailler 2012). When combined and de-duplicated, these sources provide a list of some 18,120 axeheads, each of which has a petrological description, a find location, and an object type (axehead, axe hammer, etc.). The characteristics of individual axeheads, such as dimensions, weight, and wear patterns, are not uniformly available and have not been 
considered in this study. From this overall set, we have then only kept those that are clear Neolithic axeheads, thereby by excluding other implement types such as axehammers and objects without a clear type attribution. Our focus in what follows is also primarily on the Early Neolithic ( 4100-3400 BCE), and hence, later styles such as shaft-hole axeheads (Roe 1968, 1979) have also been removed. Similarly, in the case of materials of known source, we only consider those sources exploited in the Early Neolithic on the basis of their radiocarbon dates (see Edinborough et al. 2019) or the dates of their finds contexts (e.g. Whittle et al. 2011). Finally, we have restricted the geographical scope of the present study to present-day England, Wales, and southern Scotland, keeping only those other Scottish, Alpine, French, and Irish axehead types that have findspots in this chosen study area.

As a result of these restrictions, the final list used in what follows comprises some 5809 axeheads, and Fig. 1 presents both the basic distribution of these axeheads and a kernel density surface which provide a useful spatial statistical summary that we return to at several stages in what follows. Axeheads are not uniformly distributed, and, although areas of moderate density occur around sources in Cumbria, Cornwall, and North Wales, the concentrations of highest intensity are found in a band from the Yorkshire coast in the northeast to the Welsh borders and in a band in the south across Wiltshire and Sussex. There is also a dense concentration of axeheads in Norfolk, which, as will be discussed in detail below, is largely made up of flint axeheads.

Whether or not to include flint and other ungrouped axeheads is an important consideration. Many previous studies have been based on samples restricted to axeheads in hard stones (e.g. igneous or metamorphic rocks) and well-defined provenance groups (e.g. Cummins 1979). However, this is to ignore the many thousands of axeheads which must have been in contemporary production and use alongside the known hard-stone axehead groups, and whose presence could have influenced the
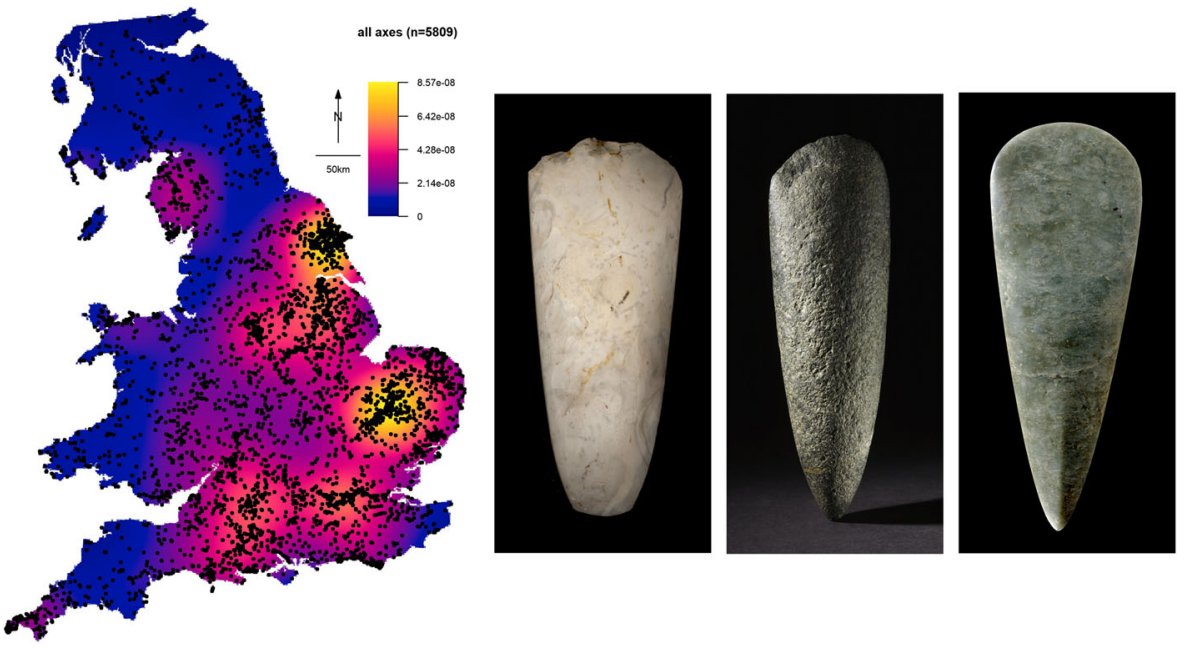

Fig. 1 The spatial distribution of all axeheads across England, Wales and southern Scotland, with a resulting model of their spatial intensity ( $n=5809$, Gaussian kernel (see text) with a one-sigma bandwidth of $30 \mathrm{~km}$ ), plus examples of (from left) flint ${ }^{1}$, greenstone (group I) ${ }^{2}$, and jadeitite axes ${ }^{2}\left({ }^{1} \mathrm{CC}\right.$ BY Birmingham Museums Trust, ${ }^{2} \subset$ The Trustees of the British Museum) 
eventual distribution of the hard-stone axeheads. A common argument against the inclusion of flint axeheads is that there is no way to be sure of their date, but previous work on the radiocarbon dating of both hard-stone quarries and flint mines has shown that, with the exception of Grime's Graves, their exploitation was particularly a phenomenon of the Early Neolithic (Edinborough et al. 2019). It is thus reasonable to infer that large numbers of flint and stone axeheads were produced in this early period, and that they should therefore be assessed jointly in any analysis. Of course, it is possible that some flint axeheads were not produced from mined flint but rather from local surface resources, and hence, that the radiocarbon dating of the mines is insufficient as a guide to chronology, but there is at least some evidence that axeheads made of surface flint too are likely to be Early Neolithic in date (Barry Bishop pers.comm., for East Anglia).

Table 1 breaks down the sample used in this paper according to different IPG groups (see Smith 1979) and their attributed sources. It also assigns axeheads to coarser macrogroups for those stones that come from the same broad region of Britain. While there have been attempts to identify even more precise sources within existing source areas using geochemical fingerprinting, and these have met with some success (Markham and Floyd 1998; Markham 2009; Davis et al. 2009), such techniques have not as yet been applied consistently across the sample, and for the purposes of the present analysis, a more approximate source location within $c a .50 \mathrm{~km}$ is more than sufficient.

In contrast to the hard-rock axeheads, deciding on one or more assumed points of origin for flint axeheads is difficult, because flint was clearly sourced from numerous locations across the south-east (Holgate 1995, Fig 1) and only a few of these have been conclusively identified or indeed dated. In this study, we do not consider the well-known site of Grime's Graves specifically, as despite a large number of radiocarbon dates, activity at the site has so far consistently been dated to 2650-2400 BCE which would place it in the later Neolithic (Smith 1979; Healy et al. 2018). It remains possible in our view that the large number of dates from Grime's Graves does not capture the full use-profile through time of the site,

Table 1 The regional groups and their component frequencies (a* means that the location is only a more general one)

\begin{tabular}{lrllr}
\hline Provenance group & $N$ & Source & Regional macro-group & $N$ \\
\hline Group I & 389 & Mount's Bay area* & A. Cornwall (I, II, IV, XVI, XVII) & 546 \\
Group II & 11 & St Ives area* & \\
Group IV & 56 & Callington area* & & \\
Group XVI & 74 & Camborne area* & & \\
Group XVII & 16 & St Austell area* & B. Cumbria (VI, XI) \\
Group VI & 1485 & Great Langdale and Scafell Pike area & B. & \\
Group XI & 6 & Great Langdale area & C. Wales North (VII, XXI) \\
Group VII & 361 & Graig Lwyd & & 1491 \\
Group XXI & 22 & Mynydd Rhiw & D. Wales South (VIII) & 111 \\
Group VIII & 111 & Southwest Wales* & E. Flint/chert \\
Flint/chert & 1512 & Multiple sources in Norfolk, & \\
& & West Sussex, and Wiltshire & F. Other & 1766 \\
\hline
\end{tabular}


because only a small, spatially concentrated proportion of the mines at Grime's Graves have been excavated and dated, but regardless, it is fair to assume that East Anglian flint was nevertheless an important Early Neolithic resource - whether coming from a different part of Grime's Graves, from another mining site, or from surface material (Frances Healy and Barry Bishop pers. comms.). This is in keeping with the fact that for all the known hard-rock sources, there is a decrease in relative quantity with distance from source, as there is for flint when we assume a source in East Anglia as well as the southern English flint mines (see below). For what follows, we therefore add a notional approximate point of origin at the centre of the overall density of East Anglian flint axeheads (some $16.5 \mathrm{~km}$ southwest of Grime's Graves) to the better-defined Early Neolithic sources of mined flint on the English south coast.

We also consider it worthwhile to retain and treat as an "Other" category all axeheads that are neither flint nor attributable to a clear petrological group (and that do not belong to clear later Neolithic shapes or groups). This “Other” category ( $n=1766)$ covers over 330 different terms for the rock used, the great majority of which ( $>310)$ occur ten times or less; 205 occur only once. The majority of these axeheads ( $>550)$ are undifferentiated greenstones and tuffs petrologically similar to Cornish and Lake District groups, which could belong to one of the groups found there but which are either variants or perhaps have not received the same level of specialist microscopic analysis. Without examining and sampling each axehead individually, there is no reliable method for grouping these axeheads, so we have adopted the conservative position of leaving them in the "Other" category. This also includes some known groups whose sources are outside the study area, such as porcellanite from Ireland ( $n=91$, the third most frequent category), and a small number of axeheads with only-vaguely understood origins (such as group XXVI, probably in Yorkshire), all groups whose numbers are too small to justify separate analysis. Furthermore, many axeheads will never be assigned to a group, as they are made of materials, such as sandstone, so widespread that their sources are extremely hard to pin down. However, because all these axeheads when taken together are quantitatively important, their influence on the distribution of grouped axeheads cannot be ignored, hence our creation of the "Other" category.

A final point to note in this section is that it is almost impossible to assess properly the factors that might have affected the distance that axeheads travelled from their source without also considering the likely uneven spatial distribution of the contemporary Early Neolithic human population who used them. As a proxy with which to infer such patterns of Early Neolithic population, we therefore make use of a database of spatially referenced radiocarbon dates (see Schauer et al. 2019 for details of sources) that we restrict both to those falling within our geographic area and within the time bracket of 4100 to $3400 \mathrm{BCE}(n=1550)$, when known axehead-producing flint mines and quarries in Britain were in use on the basis of the available radiocarbon dates from their sources (see Edinborough et al. 2019). Finally, although forming only a very small minority, those dates relating to hard-rock quarrying and flint mining have been removed from these lists to ensure that they offer independent lines of evidence.

\section{Methods}

Our analysis proceeds below in three stages. First, we explore the varying structures of axehead distributions in the study area, then we consider the relationship between 
axeheads and distance from source, and finally we compare both the observed overall density of axeheads and the regional diversity of their materials with a proxy for varying densities in Neolithic human population across the study area. This involves the following methods:

\section{D and 2D Kernel-Based Estimates of Raw and Proportional Intensity}

Focusing on the largest four IPG groups and flint across England, Wales, and southern Scotland, we provide a first, summary, mapping of the "raw" 2D spatial intensity of axeheads in a particular group, in the same manner as conducted for the entire axehead assemblage in Fig. 1. This summary is constructed by passing a Gaussian kernel (a smoothing function in the form of a two-dimensional normal curve) with a one-sigma bandwidth of $30 \mathrm{~km}$ across the study area and, for each raster cell, calculating a distance-weighted density per unit area for the kernel centred on that cell (a standard spatial statistical and GIS technique, but here using a continuous rather than distanceclipped kernel: see Baddeley et al. 2015, pp. 168-173). The kernel size was chosen as a compromise between the different values suggested by automatic bandwidth selection routines and, furthermore, was based on informal assessment of what bandwidth would minimise erratic behaviour in sparser areas of the dataset. Figure 2 shows an example using group VI axeheads from the Langdale source in Cumbria.

A second complementary form of kernel-based mapping is a "relative risk" surface (Kensall and Diggle 1995; Bevan 2012; Baddeley et al. 2015, pp. 581-585; Smith et al. 2015), and in particular, we use here a version in which the kernel density of a focal case (e.g. all stone axeheads from a particular source) is divided by the kernel density of the total known evidence (e.g. all stone axeheads irrespective of source). Figure 2c provides an example, again using group VI axeheads from the Langdale source, where each raster cell expresses the local proportion of Langdale axeheads (i.e. a value between 0 and 1) which can be compared to the global proportion of identified Langdale axeheads in the dataset $(1485 / 5809=0.256)$. Although such maps of spatially varying proportions occasionally exhibit misleading artefacts in areas of overall low data, they offer useful, improved perspectives on spatial variability by controlling, in some senses, for underling preservation or investigative bias. For example, while the raw intensity of Langdale axeheads mapped in Fig. $2 b$ retains many of the regional research biases present in the basic map of all axeheads shown in Fig. 1, by dividing the former by the latter, a more coherent $2 \mathrm{D}$ perspective of fall-off from the Langdale source is achieved (Fig. 2c).

The above maps are 2D in nature, but traditionally, the fall-off of archaeological artefacts from a known point source has also been modelled as a 1D curve. Figure 2a, for example, expresses this fall-off for a series of 50-km zones with increasing distance from the Langdale source.

\section{Predicted 1D and 2D Relative Intensity}

There are various decay models that might be fitted to such a 1D fall-off (e.g. linear or exponential) and these were extensively discussed in the exchange mechanism literature of the 1970s. In particular, Renfrew's $(1975,1977)$ down-the-line model of exponential fall-off, in which each link in an exchange chain keeps some material for 

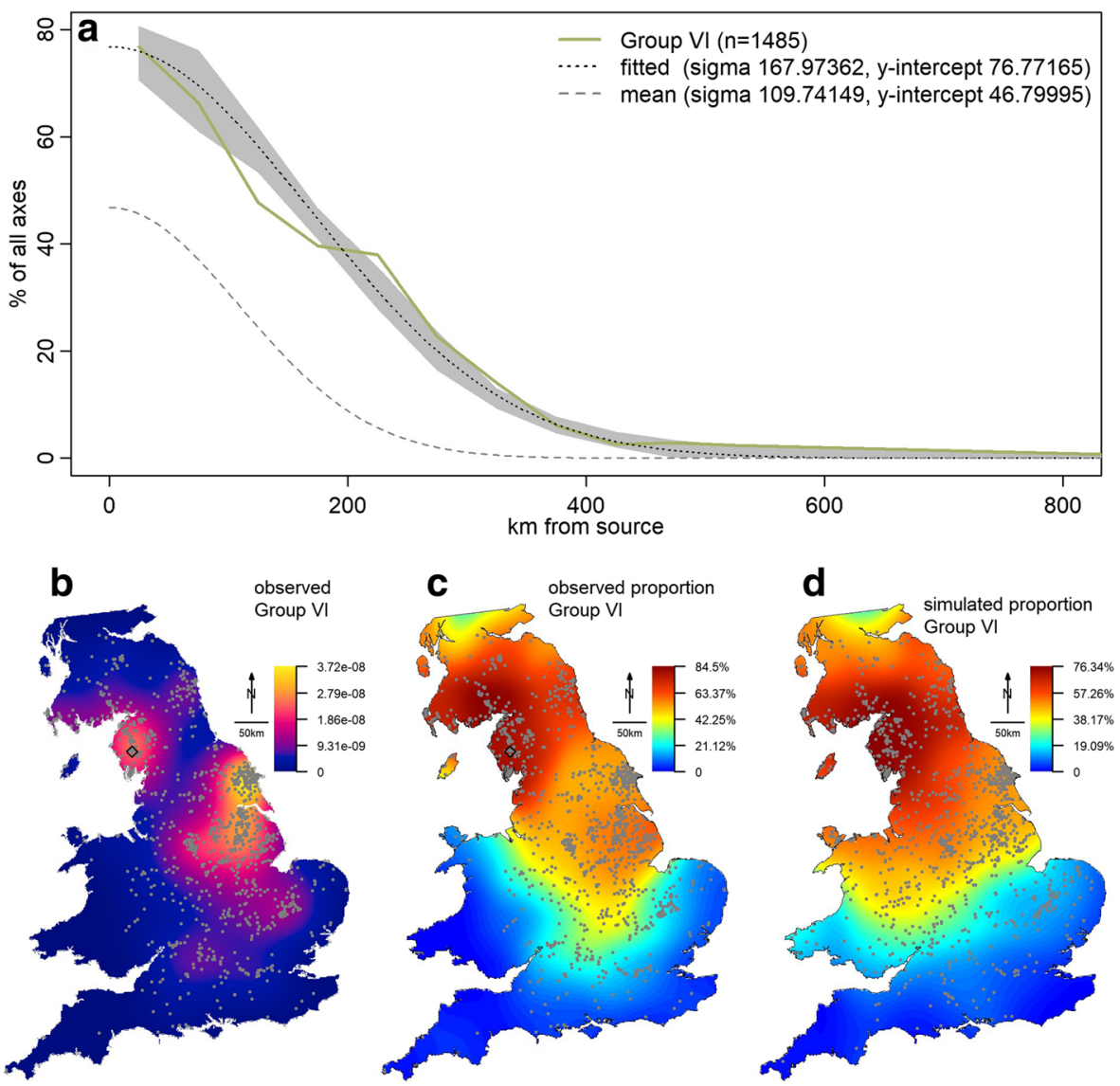

Fig. 2 Example of 1D and 2D summaries and simulation of the axehead distribution from Langdale (group $\mathrm{VI}$ ). a The vertical axis indicates the percentage of group VI axes in a series of $50 \mathrm{~km}$ distance bands away from the source; the solid green line corresponds to the actual percentage; the dotted grey line corresponds to the percentages predicted under a Gaussian random walk model (see text); the grey band around it is the $95 \%$ critical envelope around the percentages created by the model, created by randomly permuting the assignment of axeheads to sources and generating the corresponding fall-off 1000 times; the dashed line corresponds to the fitted average fall-off across all stone groups. b The raw spatial intensity of group VI axeheads. $\mathbf{c}$ The relative intensity as a proportion of all axeheads. d A simulated model of group VI proportions in 2D given the Gaussian random walk model fitted in Fig. 2a in 1 dimension

its own use and passes on the rest, has been widely influential. Here, however, we find that a Gaussian-shaped decay not only proves to be the most consistently useful across all groups (for example in group VI, AIC Gaussian=72.289, exponential AIC= 84.028, and power law $\mathrm{AIC}=110.601$ ). This is also consistent with a minimal starting assumption, given we will never know the histories of movement of individual axes, that any axehead might move from its place of manufacture in steps of random length and direction, either with its users or when exchanged between them, before reaching a final resting place in the ground (i.e. a random walk). We have also preferred to use Euclidean distances from a source rather than a more complicated terrain-weighted distance model, as there was no initial evidence that a more complicated model would offer greater explanatory power. The fitted Gaussian decay was then compared with the 
observed decay using a two-sided Kolmogorov-Smirnov test. Model fitting was conducted for the four largest IPG groups (I, VI, VII, VIII, as per Table 1) plus flint, and a 95\% critical envelope around the model fit was generated by permuting the membership or not of a known axehead to the source of interest according to the fitted distance fall-off and repeating this process 1000 times. Finally, we plotted the resulting fit back onto the map (Fig. 2d) as a point of comparison with the observed 2D proportions (Fig. 2c).

\section{Regional Classification Via K-Means Clustering}

Given a set of several 2D proportion maps such as the one in Fig. 2c, we can stack up the resulting raster images and group regions of the map together via unsupervised classification, in the same manner as might be done for a multispectral image. That is to say, we combine the relative intensity maps for all the stone sources so that each map cell has its own specific combination of stone types. Raster cells/pixels that exhibit similar proportion values for axeheads from the different stone sources are thereby grouped together. It turns out that when pixels are grouped together solely on the basis of having similar proportions of axeheads from different sources, the resulting clusters or groups form spatially coherent regions. Amongst a range of alternative clustering methods, here we use $k$-means (for the general method amongst a wider set of numerical classification applied in archaeology, see Shennan 1997, pp. 190-240; and for its use for unsupervised classification of stacked raster surfaces, see Richards 2013, pp. 319-341) and explored a series of different numbers of cluster groups. We opted to focus our interpretation on the patterning obtained with six groups (see results below). To address as much regional patterning as possible, this $k$-means grouping was conducted on the stone macro-groups (see Table 1) rather than individual IPG groups, although it is worth noting that this choice does not significantly change the overall interpretations that we draw below.

\section{Random and Conditional Simulation of Axehead Material Types}

One important question is how well different models of distance fall-off fit the observed diversity of axehead materials found in each of the six classified regions of the UK. We here express within-region diversity via a Simpson index (Simpson 1949; and for the wider family of diversity indices, see also Chao et al. 2014). We then fit a series of three models to the diversity data, starting with an extremely simple model 1 in which each observed axehead find is assigned a new stone macro-group completely at random. Model 2 adds a distance-from source "supply" effect which is the same for all macrogroup sources (i.e. the dashed line in Fig. 2a). At a given observed findspot of an axehead, the simulation selects a stone macro-group for that axehead which is conditioned on how far we are from each macro-group source. For example, if the axehead findspot is equidistant from source $\mathrm{A}$ and source $\mathrm{B}$, then simulation will assign an equal chance to the axehead's stone type being from one of these sources, but a lesser chance for source C if the latter is further away. Model 3 further adjusts for variable "demand" by imposing a specific distance decay from the observed data for each stone source (i.e. the dotted rather than the dashed line in Fig. 2a). Hence, at a given observed findspot of an axehead, the simulation selects a stone macro-group for that axehead conditional on 
the relative distance from each of the sources, but also adjusted for the particular observed decay profile of that source. This means that if source A has an observed distance decay which suggests greater popularity and greater geographical reach than an alternative source B, then at an observed findspot equidistant between these two sources, source A will be more often chosen as the simulated stone type. All three models only consider diversity in the counts of groups I, VI, VII, VIII, and flint ("Other" is left out). The goal of these simulations is to produce hypothetical axehead distributions and expected diversity measures by region.

\section{Comparison with Inferred Population, Monumental Enclosures, and Material Culture}

We also compare, both informally and formally, the observed density and diversity of axehead stone types (in each region of the UK defined by the $k$-means method above) to (a) a radiocarbon-based proxy for the possible distribution of Early Neolithic population, (b) Neolithic causewayed enclosures, and (c) Early Neolithic pottery styles. The use of radiocarbon dates as a proxy for population has been extensively discussed in the literature (e.g. Timpson et al. 2014; Timpson et al. 2015; Tallavaara et al. 2014; Edinborough et al. 2017), responding to criticisms). In the case of Britain, it has been shown that periods of high population as inferred from the radiocarbon dates coincide with evidence from pollen diagrams indicating high levels of human impact on the vegetation in the period 4100-3400 cal BC on which this paper is focussed (Woodbridge et al. 2014), strongly suggesting that it is reasonable to use the dates in this way. Moreover, we find very similar patterns of inferred population in different parts of the British Isles (Bevan et al. 2017). In addition, comparison of the overall density of UK radiocarbon dates in Fig. 1 in that paper with this paper's Fig. 9 shows that the low number of earlier Neolithic dates from East Anglia, for example, contrasts with the high number of dates for all periods from that region, confirming that such patterns are not an artefact of differences in fieldwork intensity.

In particular, we compare the densities of axeheads in each $k$-means region with, separately, the density of radiocarbon dates and the density of enclosures, which indicates whether there is significant covariance between these within each region (for the technique, see Baddeley et al. 2015, pp. 307-9). Furthermore, we formally compare the residuals of the best-fitting simulation model of axehead materials (see the previous section) against radiocarbon date densities to consider whether higher or lower inferred population density per region might add further predictive power and thereby suggest that "demand" in high population areas drove yet higher levels of axehead material diversity.

\section{Results}

\section{Observed and Simulated 1D and 2D Distributions by Individual Group}

Figures 3, 4, 5, and 6 use the same method introduced above for Fig. 2, but apply them to three other IPG groups and to flint axeheads. For example in Fig. 3a, group I axeheads are found to represent $18.18 \%$ of all axeheads within $50 \mathrm{~km}$ of group I's 

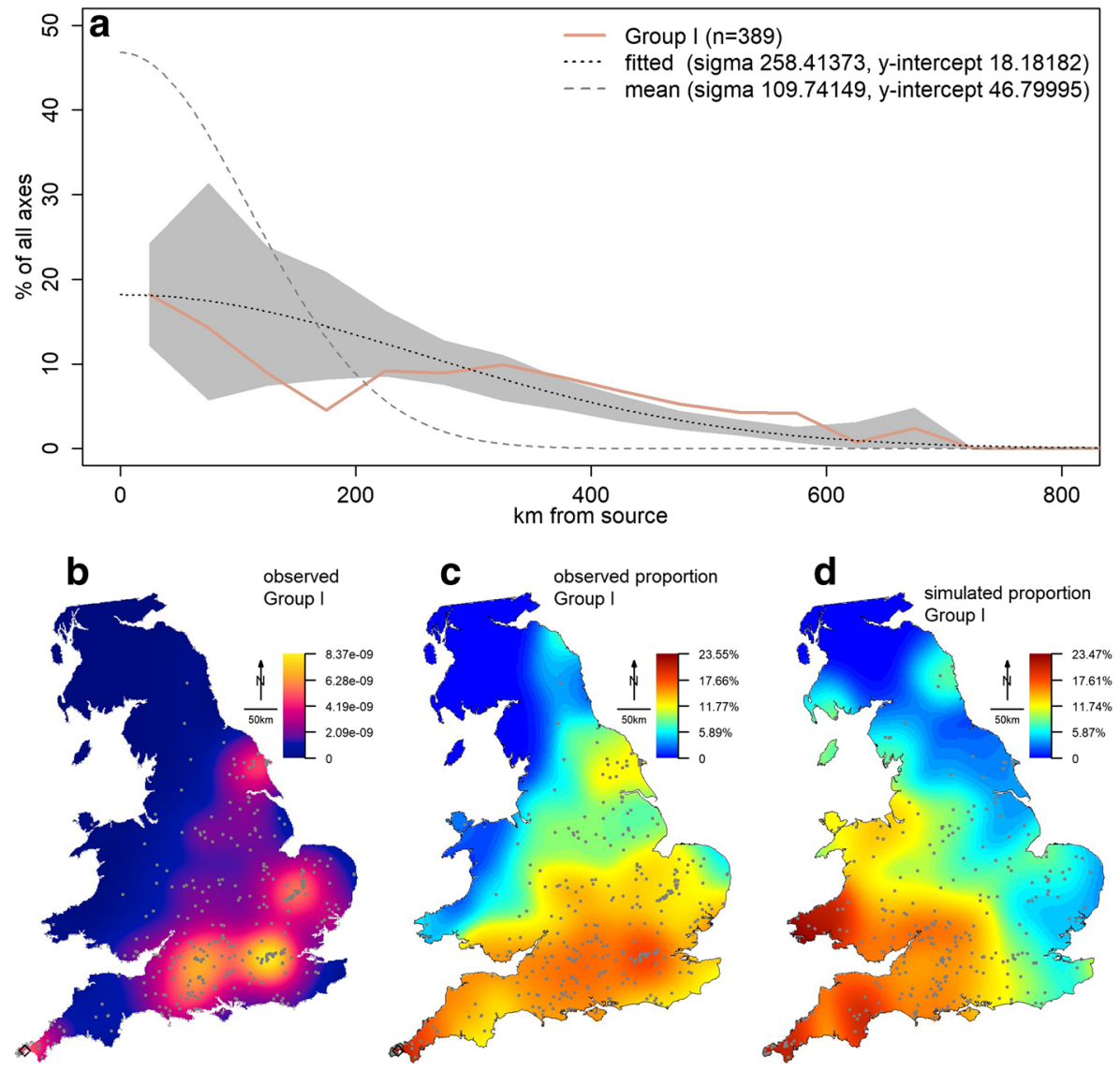

Fig. $31 \mathrm{D}$ and 2D summaries and simulation of the axehead distribution from the Mount's Bay area in Cornwall (group I): a 1D fall-off curve, with a Gaussian fitted model and resulting simulation envelope (and additionally a dotted line representing the average model across all stone groups); $\mathbf{b}$ the raw spatial intensity of Group I axeheads, $\mathbf{c}$ the relative intensity as a proportion of all axeheads, and the $\mathbf{d}$ a simulated model of group I proportions in $2 \mathrm{D}$ given the fitted $1 \mathrm{D}$ fall-off

source (30 out of 165 axeheads found in that 50-km bin). In Fig. 3b, the raw density of finds primarily shows where most of the group I axeheads have been found, in southeast and south-central England, while the proportion of group I axeheads versus all axeheads is mapped in Fig. 3c. Figure 3d shows a prediction surface based on the fitted 1D Gaussian fall-off model and comparison with Fig. 3c emphasises how this underpredicts the observed proportions of group I axeheads getting to the south-east and over-predicts those getting to South Wales.

Similar insights are possible from the plots in Figs. 4, 5, and 6. Groups I, VI, VII, and VIII differ significantly from the mean fall-off curve (two-sided KolmogorovSmirnov test, $p<0.0001$ ), with the Welsh sources not travelling as far afield as the Cornish (I) and Langdale (VI) groups. In contrast, the fall-off of flint axeheads, from several real or inferred sources in the south-east, is indistinguishable from the average observed pattern $(p=1)$. 

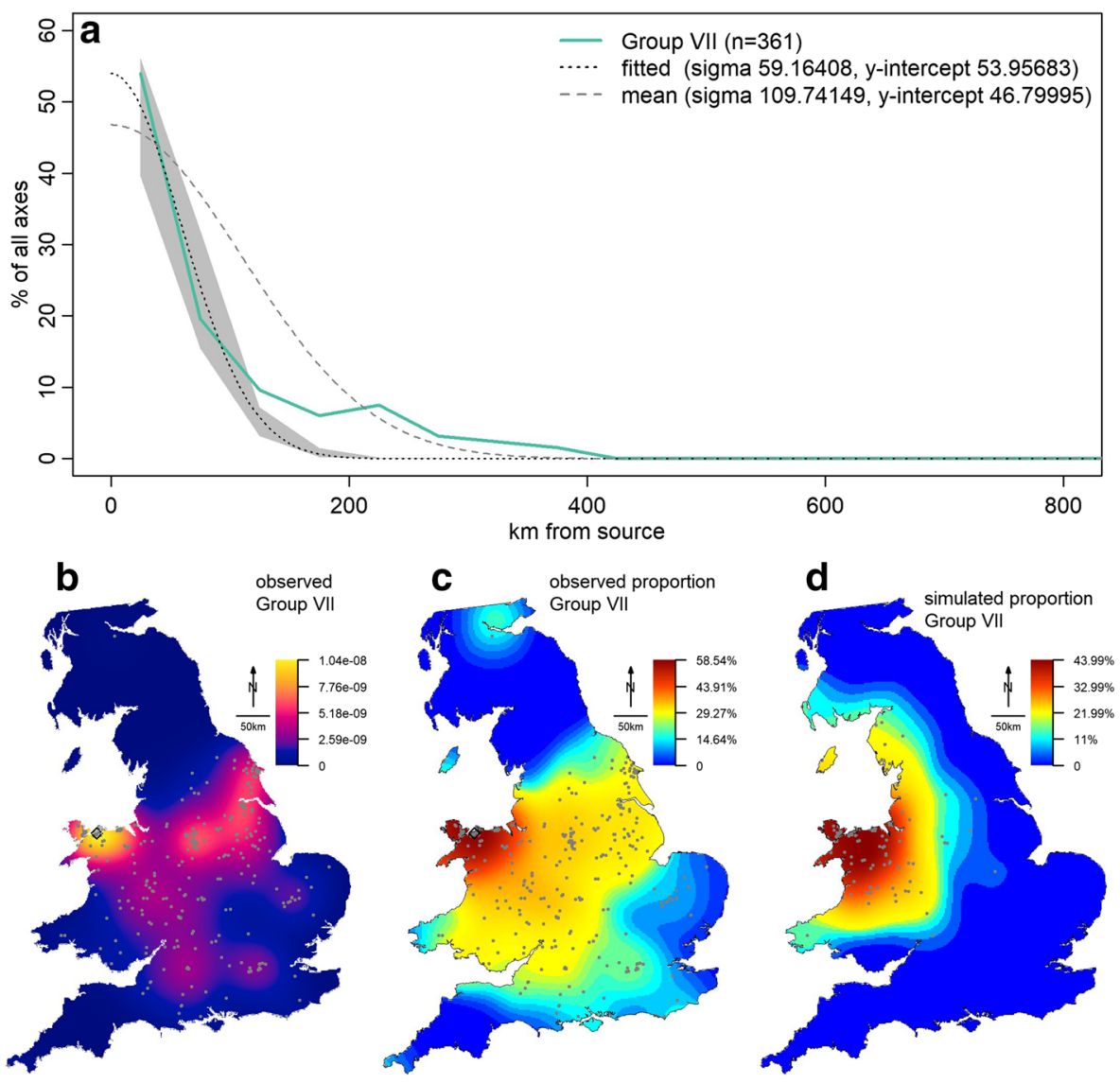

Fig. 4 Group VII. Details as Fig. 3

\section{Regional Classification Via K-Means Clustering}

As described above, to address regionalism in stone axehead finds more broadly, those IPG petrological groups sourced to similar regions were lumped into five macro-groups (and a sixth "Other" category, see Table 1) and proportional intensity maps (similar to Figs. 2c and 3c, etc.) were calculated for each one. These were then stacked up and classified using an unsupervised $k$-means classifier for a series of different choices of the number of clusters $(2,3,4,6$, and 8$)$ as presented in Fig. 7. At each successive number of clusters, regions with the highest proportion of a single group of axehead are split from the remaining axeheads, starting with the Cumbria group, then flint/chert, then Cornwall, and so on. Selecting six divisions produces a plot in which each cluster contains one major source, with the exception of clusters 2 and 6, though sources are not used as an input in this analysis. Cluster 6 effectively surrounds cluster 1, covering the midlands and north of England, a small area of southern Scotland, and the Isle of Man, all areas dominated by group VI axeheads but with a greater presence of other groups than cluster 1. It includes a concentration of axeheads on the Yorkshire coast, which forms the northeast end of the high-intensity band of axehead frequency seen in 

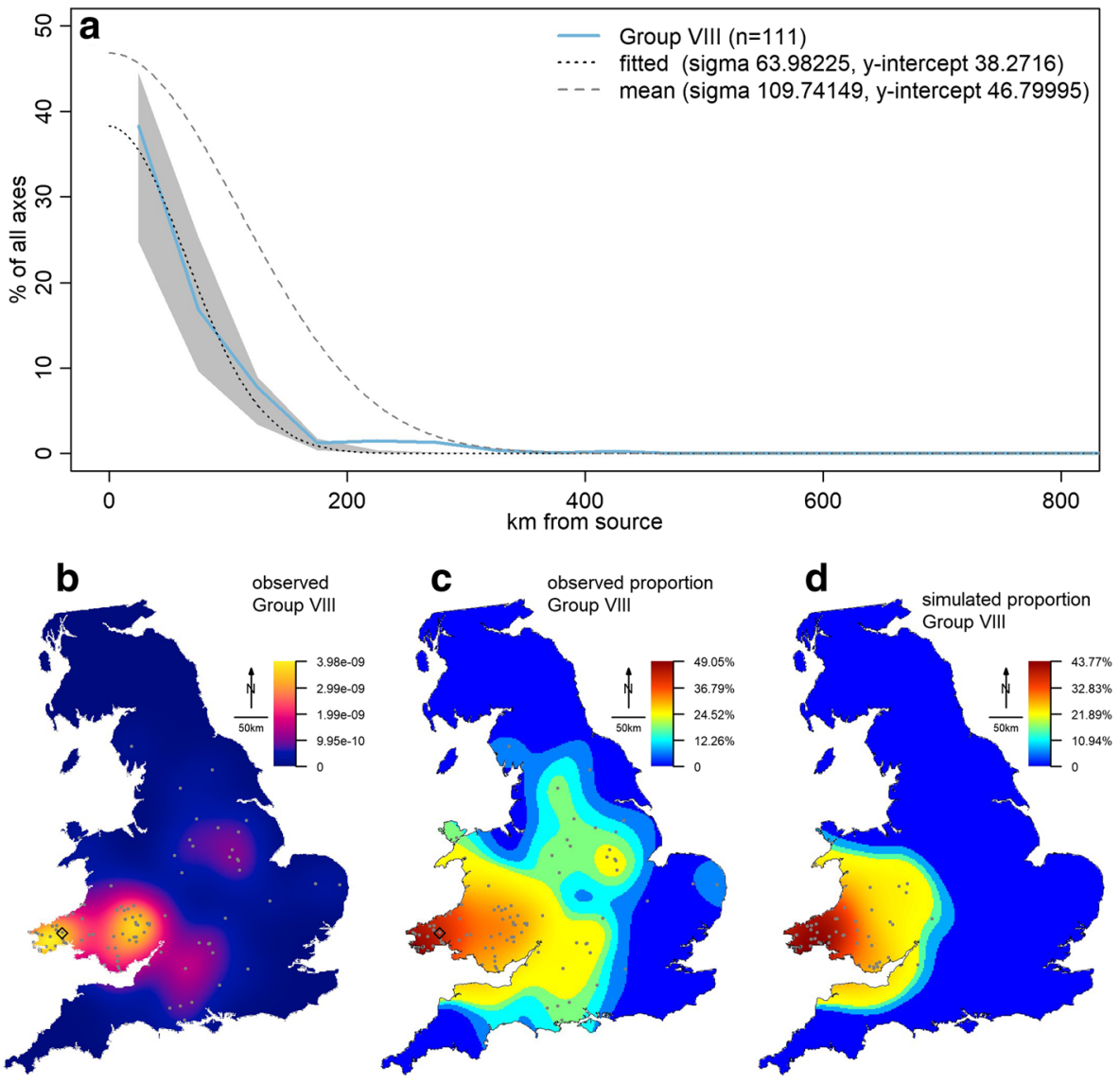

Fig. 5 Group VIII. Details as Fig. 3

Fig. 1. Several axehead groups originate in cluster 6, including groups XII, XIV, XVIII, and XX, but these are not included in this study due to their appearance in the later Neolithic/early Bronze Age (Smith 1979). Cluster 2 contains both the South Wales source and several flint sources, which are split between clusters 2 and 4.

The bar plots in Fig. 7 show the frequencies of each axehead group in each cluster, using the 6-cluster solution as an example. Axeheads in the "Other" group make up between $20.7 \%$ (cluster 4 ) and $49.86 \%$ (cluster 5) of each cluster, compared to an overall proportion of $30.4 \%$ (Table 1). The large number of "Other" axeheads in cluster 5 is mostly composed of ungrouped greenstone axeheads, which might be unidentified members of group I, the most numerous of the Cornish greenstone types.

The relative numbers of the different axehead groups in cluster 2 most closely match the relative numbers in the overall sample shown in Table $1(p=0.0358)$. All other clusters are very different from this distribution, as would be expected, given that the $k$ means process clusters areas of neighbouring raster cells whose axehead findspots exhibit similar proportions of stone types and that we would expect axeheads to cluster around their sources. The separation of sources in the $k$-means regions might indicate something about the structure of the Neolithic axehead distribution system. 

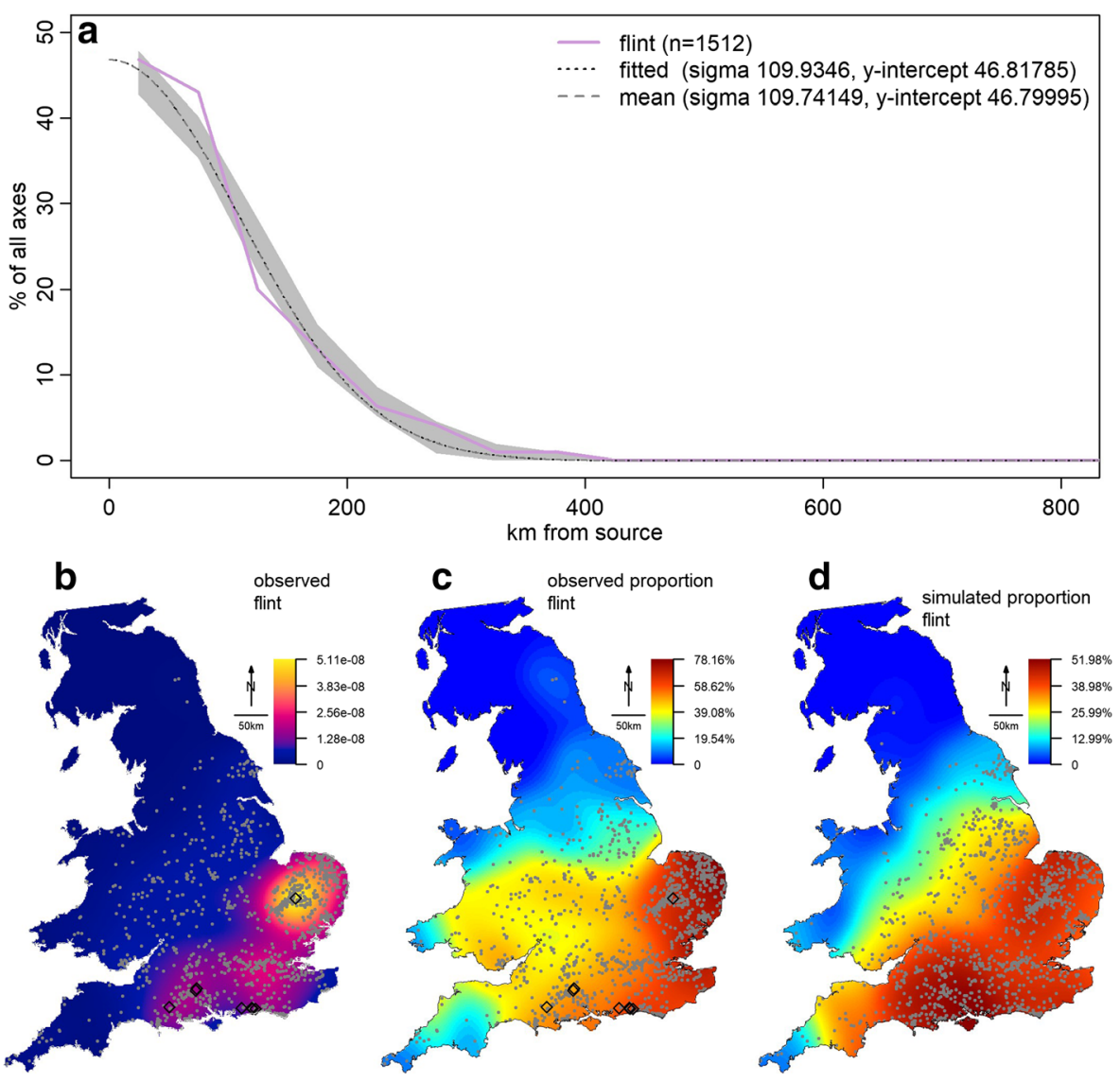

Fig. 6 Flint. The source points include mines and quarries with early Neolithic dates, plus a point in East Anglia which is placed at the centre of the area of overall maximum flint density. This point happens to be only $16.5 \mathrm{~km}$ southwest of Grime's Graves

\section{Inferred Population from Radiocarbon Dates and Axehead Intensity}

Figure 8 compares the summed probability distributions (SPD) for three dated sources of hard-stone axeheads and ten dated sources of flint, using anthropogenic radiocarbon dates collected as part of the NEOMINE project (see Edinborough et al. 2019). These dates are each compared with an SPD made up of dates found within a 1-km hinterland of each axehead of each type, with hinterlands merged when axeheads were found in close proximity so that dates are counted only once for each plot. All SPDs are made up of an envelope of dates created by sampling no more than 5 dates per site, in order to limit the effects of oversampling of certain sites, such as Grime's Graves. This sampling was repeated 1000 times for sources and 100 times for axehead hinterlands to produce 95\% envelopes around these estimates. The resulting plot suggests that the period of peak intensity was actually slightly earlier for flint, between 4000 and $3700 \mathrm{BCE}$, than for stone, which peaked between 3900 and 3600 BCE.

We can plot the 6-cluster $k$-means regions onto a density map of radiocarbon dates from 4100 to $3400 \mathrm{BCE}(n=1550$, Fig. 9). There are similarities and differences 


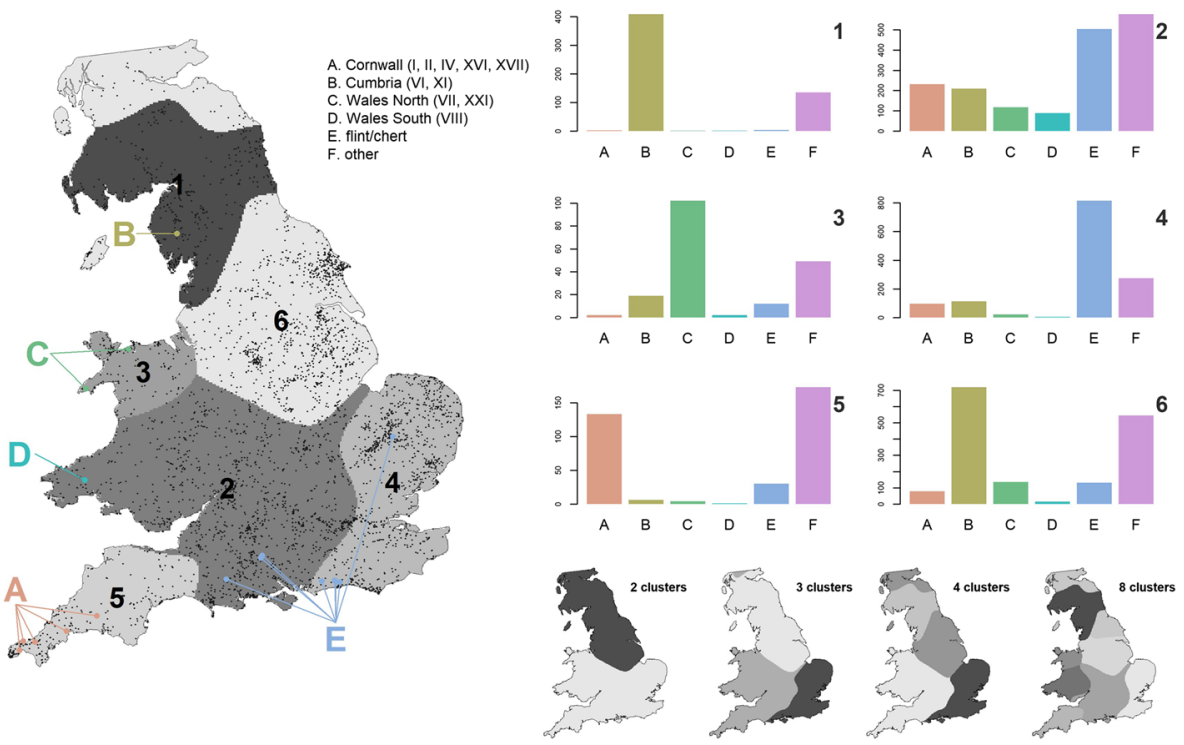

Fig. $7 \mathrm{~K}$-means plots, with counts of the different stone macro-groups per cluster and alternative divisions using different cluster counts. As explained in the text, the clusters are created by grouping together all map cells that have similar proportions of the various stone groups. When mapped, these clusters form spatially coherent regions. The bar charts show the counts of the different stone groups in each cluster region

between the date and axehead density plots: the largest area of high date intensity corresponds with the southern and western parts of cluster 2, an area into which the distribution for every axehead group extends (Figs. 2b, 3b, 4b, 5b, and 6b). However, the high flint concentrations in Norfolk (see Fig. 6b) correspond with an area of very low population density during this period (cluster 4). Table 2 provides a summary of modelling the degree to which the density of axehead finds covaries with the density of Early Neolithic radiocarbon dates (the latter being adopted as a population proxy; see
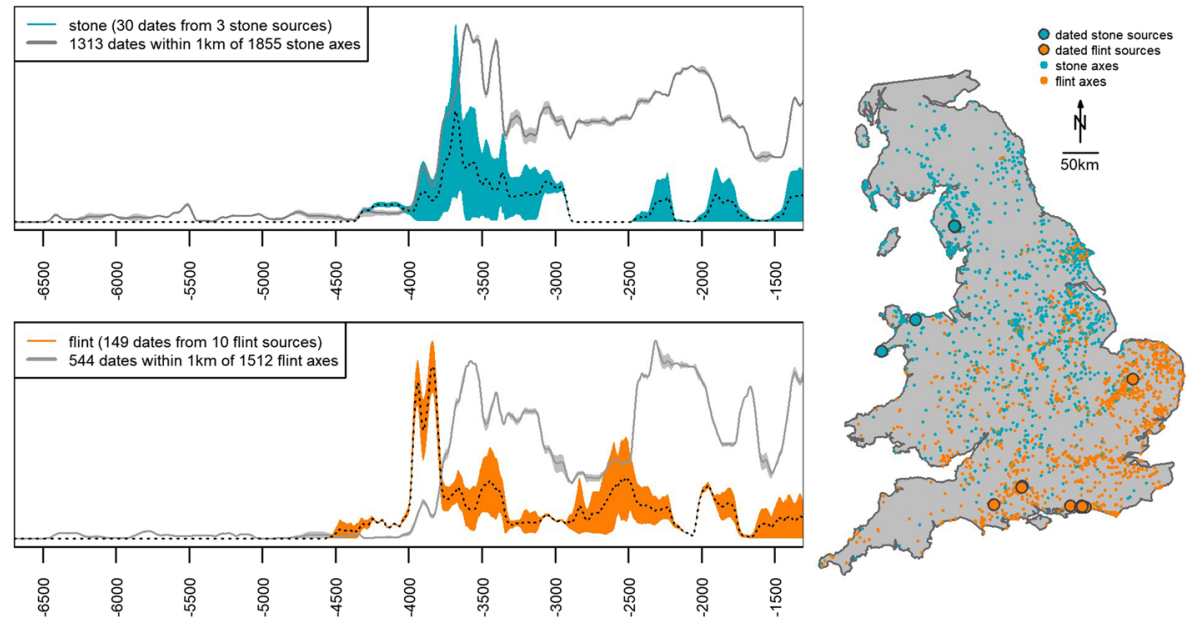

Fig. 8 Stone versus flint. Mine SPD formed by sampling, no more than 5 dates per site 1000 times, and hinterland SPD formed by sampling dates within $1 \mathrm{~km}$ of each axehead, no more than 5 dates per site, 100 times. Only axeheads from dated quarries are included in the stone sample 

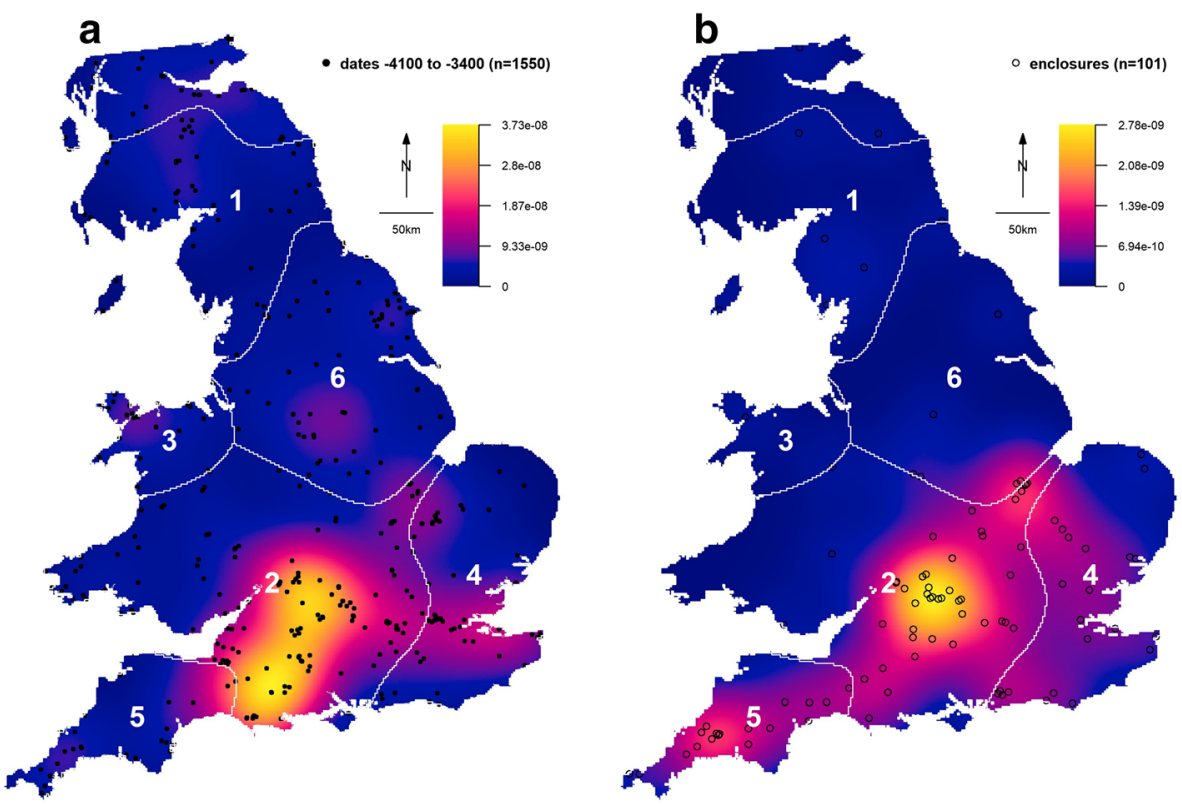

Fig. 9 a Radiocarbon date density (excluding mine dates) (points) and b Early Neolithic enclosures (open circles) (Oswald et al. 2001), with the $k$-means boundaries added

also the distribution of long barrows: Darvill 2016: Fig.1A). There is a significant negative relationship in clusters 1 (Cumbria/southern Scotland) and 4 (Norfolk), such that areas with higher numbers of dates are not those with higher numbers of axehead finds. This is unsurprising for Cumbria as an agriculturally more marginal zone in an area of axehead production, but is more surprising for Norfolk, where the low, open landscape contains few obstacles to settlement. In contrast, there are also significant positive relationships in all other clusters, where areas with large numbers of dates generally correspond with many axehead finds.

Table 2 Modelled covariances (within each $k$-means region and overall) between axehead findspot densities and kernel density surfaces of (a) radiocarbon dates and (b) Neolithic enclosures. Z-scores suggest the strength and direction of covariance while asterisks indicate significance at $* 0.05$, $* * 0.01$, and $* * * 0.001$ levels respectively

\begin{tabular}{|c|c|c|c|c|c|}
\hline$K$-means region & $\begin{array}{l}\text { Axehead } \\
\text { COUNTS }\end{array}$ & $\begin{array}{l}\text { Radiocarbon } \\
\text { date counts }\end{array}$ & $\begin{array}{l}Z \text {-score } \\
\text { (axeheads } \\
\text { dates) }\end{array}$ & $\begin{array}{l}\text { Enclosure } \\
\text { Counts }\end{array}$ & $\begin{array}{l}Z \text {-score (axeheads } \\
\sim \text { enclosures) }\end{array}$ \\
\hline 1 (Cumbria/southern Scotland) & 550 & 88 & $-6.7519 * * *$ & 5 & $9.5602 * * *$ \\
\hline 2 (Wessex/South Wales) & 1727 & 802 & $16.4106^{* * * *}$ & 46 & $10.3449 * * *$ \\
\hline 3 (North Wales) & 186 & 59 & $7.0248 * * *$ & 1 & $6.5786^{* * *}$ \\
\hline 4 (Norfolk/south-east) & 1319 & 207 & $-6.9884 * * *$ & 22 & 1.6324 \\
\hline 5 (Cornwall) & 347 & 98 & $4.5512 * * *$ & 18 & $-5.7721 * * *$ \\
\hline $\begin{array}{l}6 \text { (Midlands/Yorkshire/southern } \\
\text { Scotland/Isle of Man) }\end{array}$ & 1624 & 273 & $20.1131 * * *$ & 9 & $14.3838 * * *$ \\
\hline All regions combined & 5809 & 1550 & $14.767 * * *$ & 101 & $12.458 * * *$ \\
\hline
\end{tabular}


Table 2 also summarises the same kind of comparison between axehead findspot densities and Neolithic enclosure densities. There is a particular concentration of enclosures in cluster 2 (Wessex and South Wales have 46 of the 101 mapped examples, all but a handful of them in Wessex) and very significant positive correlations with axehead findspot densities in all areas except cluster 5 (Cornwall), where the relationship is strongly negative, and cluster 4 (Norfolk), where it is not significant. Depending on how we interpret the role of the enclosures themselves, this patterning is interesting either as another indication of higher populations (where enclosures are common) or as pointing to a special role for enclosures in exchange systems, such that people closer to enclosures had a higher probability of obtaining non-local axeheads. The role of enclosures in long-distance gathering and exchange has, of course, long been recognised, highlighted by their associations with axeheads, ceramics, and even individuals derived from distant origins (e.g. Peacock 1969; Evans et al. 1988; Whittle et al. 2011; Neil et al. 2018).

As noted in the "Methods" section, we can also keep observed axehead findspots constant but simulate a hypothetical macro-group for each axehead, based on a series of increasingly complex models of likely supply and demand. The observed (Simpson) diversity of different axehead materials from each cluster region can then be compared to the simulation for goodness-of-fit. Table 3 summaries the results for three such simulation models: in model 1, each axehead find is assigned a new stone macro-group completely at random. For model 2, the simulation selects a stone macro-group for each axehead findspot that is conditioned on how far it is from each macro-group source (an average, constant model of decay as expressed by the dashed line in Fig. 2a). For model 3 , the simulation imposes a specific distance decay curve derived from the observed distance model of each stone source (i.e. the dotted lines in Figs. 2a, 3a, 4a, 5a, and 6a). For all three models, we only consider diversity in the counts of I, VI, VII, VIII, and flint, excluding both "Other" and smaller groups within each region listed in Table 1. The results show that model 3 is by far the best fit to the data, with simulated diversity closely matching observed diversity in the majority of cluster regions. For example, the cluster region with the lowest observed and simulated diversity is Cumbria (cluster 1), which is dominated by group VI Langdale axeheads (Fig. 7, bar plot 1), while the greatest diversity is found in Wessex and South Wales (cluster 2). However, there remain certain discrepancies and Fig. 10 therefore shows the result of regressing the model 3 residuals against the median radiocarbon date intensity for each cluster region. There is a good overall correlation $\left(r^{2}=0.56\right)$, which implies that, above and beyond the parameters used in model 3 , higher population densities in a region are predictive of yet higher diversity in axehead materials.

A final possibility that we now consider is whether the distribution of axeheads from the different sources may be related to other cultural patterns. Pioffet (2014) has argued persuasively that early pottery styles in southern Britain can be divided into at least two groups based on differences in technical complexity and variation: style I-1a found in the east and style I-2a found in the west (Fig. 11). Similarities between these styles and pottery found in Europe indicate that there were two near simultaneous but separate inmigrations of people, with one western group arriving primarily from Brittany and another eastern group arriving from Pas-de-Calais/West Flanders (Sheridan 2010). These also represent geologically distinct zones on either side of the channel with the hard-stone resources and landscapes of the Armorican massif (of Hercynian orogeny) 


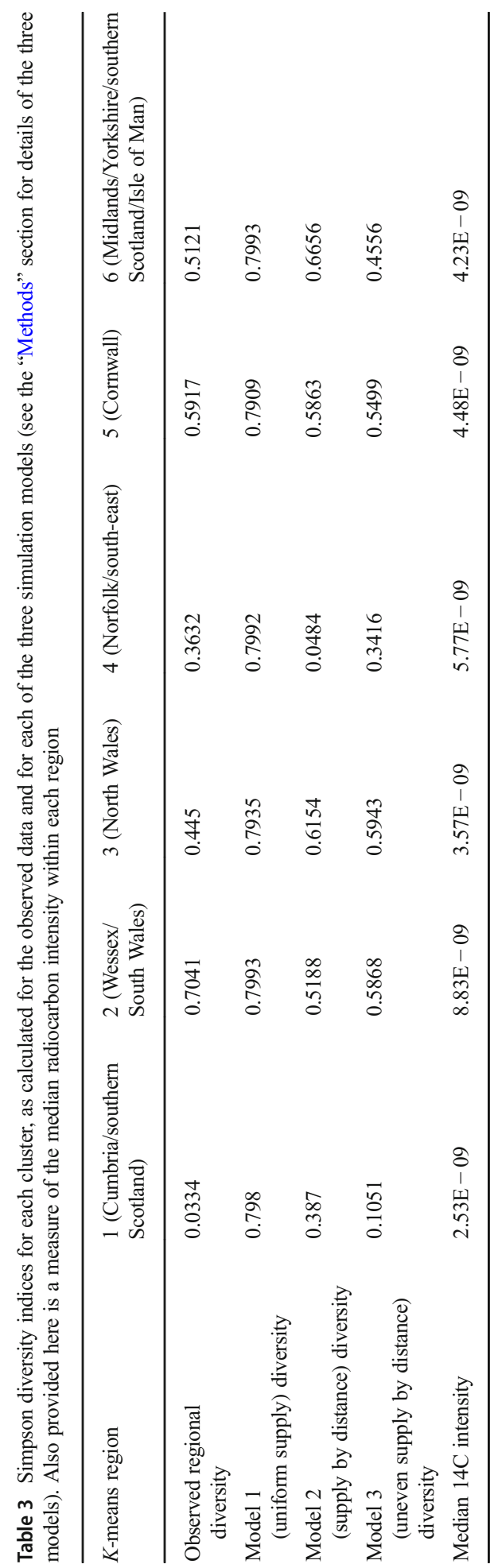




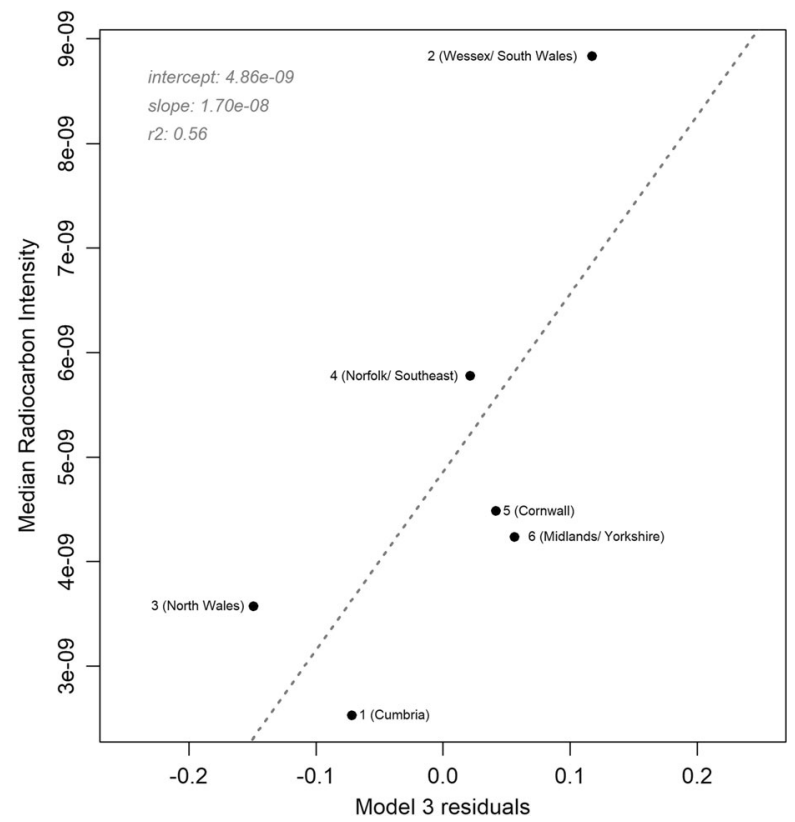

Fig. 10 Regression of Simpson diversity index residuals for simulated axehead types against the median density of dates in each region $\left(r^{2}=0.56\right)$

linked to similar ones in the English south-west, while the flint-rich Upper Cretaceous chalk deposits of south-eastern England are much closer to the landscapes and flint-
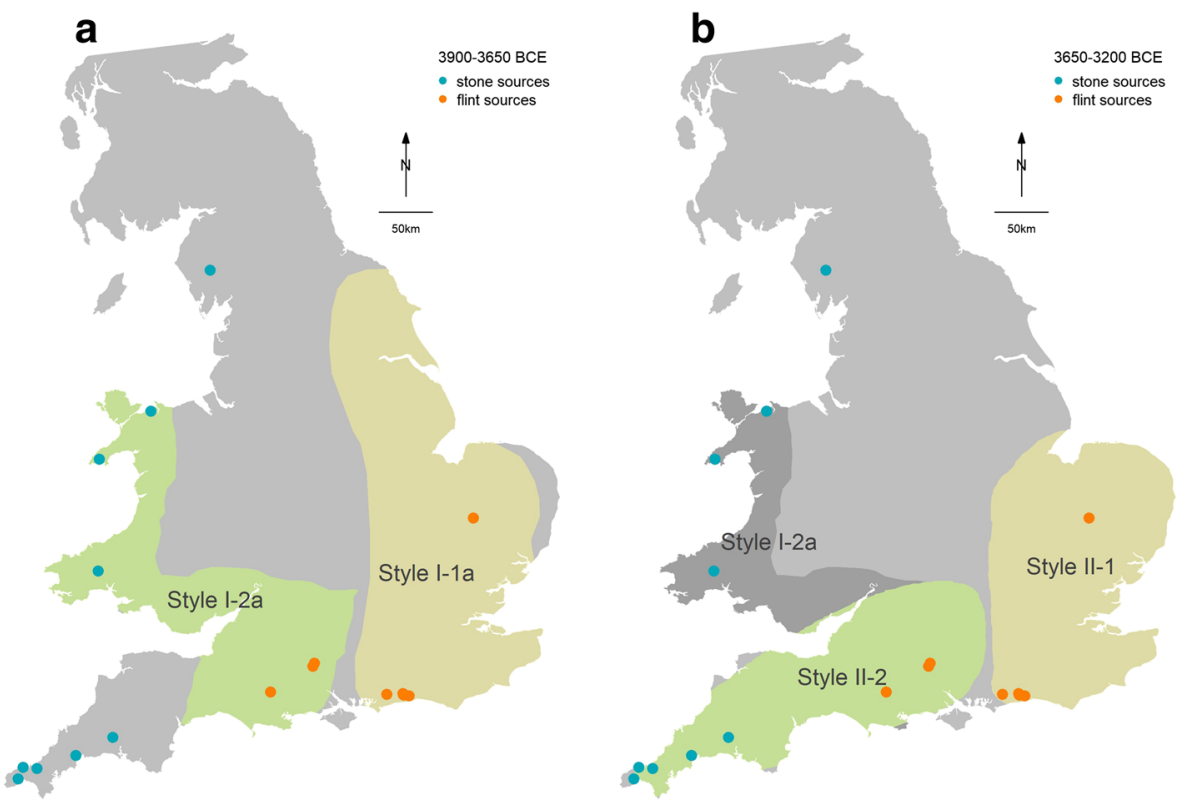

Fig. 11 Neolithic pottery style zones: pottery style zones and east/west distinctions (a) 3900-3650 BCE and (b) 3650-3200 BCE (after Pioffet 2014: figs.6.14-5) 
mining areas of neighbouring Normandy and southern Belgium (Mortimore 2012; Collin 2016; Dijkstra and Hatch 2018). Settler communities therefore could have moved to nearby locations with similar geological and ecological profiles, as well as similar axehead raw materials, with the western half exploiting hard-stone sources in Cornwall, Wales, and Cumbria and the eastern half exploiting flint from Sussex and Norfolk ( $c f$. Edinborough et al. 2019), though it has also been suggested that Langdale was associated with this tradition. In any case, there is no indication that these different putative cultural ancestries resulted in a barrier to axehead exchange. On the contrary, as we have seen, group I axeheads from Cornwall occur far more frequently in southeast England than we would expect and there are concentrations of group VI axeheads in east Yorkshire and Lincolnshire.

\section{Conclusion}

The application of our updated spatial analysis methods has enabled us to draw new conclusions concerning the factors affecting the distribution of axeheads from different sources, and to characterise them with greater rigour through the testing of different models. In summary, our overall results suggest the impact of both supply and demand factors affecting the distribution of Neolithic axeheads. The $k$-means cluster analysis and comparative inspection of the $2 \mathrm{D}$ distributions of the products of the different sources show that areas adjacent to a major hard-stone source are always dominated by that source and tend to exclude other materials; for example, there are far fewer group VI axeheads in North Wales than its distance fall-off would predict.

Yet simple proximity to nearby sources cannot fully explain the pattern of Neolithic axehead materials that we observe in different parts of southern Britain, since the fitted fall-offs of different axehead sources exhibit distinctly different curves, suggesting that certain stone types were far more popular than others and travelled more widely, especially groups I and VI. In contrast, this is not the case with flint, whose density further away from its sources is lower than predicted. In fact, the local availability of flint, and even flint mines, does not exclude the widespread occurrence of group I axeheads in southern England in the way that group VII excludes group VI in North Wales. The highest relative density of flint axeheads is greatest in East Anglia, furthest away from the group I and group VI sources; there is no zone of higher relative flint density around the southern English flint mines. The reasons why certain types travelled far more widely are not clear but one reason for the differences may be variation in the mechanical properties of the rock (cf. Pitts 1996). Thus, a study of the distribution of greenstone axeheads used by aboriginal groups in Australia showed that greenstone from the Mt William quarry, average travel distance $>200 \mathrm{~km}$, maximum $>$ $800 \mathrm{~km}$, had greater elasticity and fracture toughness than green stone from the Berrambool quarry, average travel distance $\sim 100 \mathrm{~km}$, maximum $<300 \mathrm{~km}$ (Domanski et al. 1994).

Of course, axehead findspots are places of final deposition for objects that may have had extended use-lives and multiple owners, so some of the variability we observe may have been introduced by complex axehead biographies. A flint axehead broken far from a source of raw materials might be reshaped into other implements and thereby vanish from the record (Pitts 1996, p. 325). However, it is striking that we can account for a high degree of the variability in the density and diversity of axehead materials 
across different regions of southern Britain by joint modelling of particular fall-off profiles for each source and of local demand pools provided by particularly dense areas of Early Neolithic settlement, as in central southern England. This region had the greatest diversity of axeheads, confirming earlier findings which relate increased axehead diversity to increased distance from source (Darvill 1989).

The significance of causewayed enclosures as monuments constructed and used by groups with long-distance exchange links, as supported by evidence of imported artefacts and materials found within them, is also affirmed by their spatial relationships with axehead distributions. The relationship between the density of flint and pottery finds at enclosures and their proximity to flint sources has been previously observed (e.g. Davis and Sharples 2017, Table 2), but our results emphasise the additional importance of differences in regional population density. We would therefore expect not only more enclosures in central southern England, but also for those enclosures to have a more diverse range of stone artefacts than enclosures in other regions.

Although Early Neolithic immigration seems to have come from two different regions of continental northwest Europe, this does not seem to have affected the distribution of hard-stone axeheads.

These conclusions will clearly require further attention with fresh data in the same study area (as is currently being collected by the IPG, for example) or for analogous regions elsewhere in Europe, but point to some of the factors influencing supply-anddemand in the British Early Neolithic.

Acknowledgments We are grateful to The Leverhulme Trust for Grant RPG-2015-199, for the project "Supply and demand in prehistory? Economics of Neolithic mining in NW Europe," that made the project possible, to Gabriel Cooney for Irish axehead data, and to Frances Healy and Barry Bishop for information about axeheads and flint sources in East Anglia. We used the $\mathrm{R}$ statistical environment for all analysis ( $\mathrm{R}$ Development Core Team 2008), especially the spatstat (Baddeley et al. 2015) and rcarbon (Bevan and Crema 2018) packages.

Open Access This article is licensed under a Creative Commons Attribution 4.0 International License, which permits use, sharing, adaptation, distribution and reproduction in any medium or format, as long as you give appropriate credit to the original author(s) and the source, provide a link to the Creative Commons licence, and indicate if changes were made. The images or other third party material in this article are included in the article's Creative Commons licence, unless indicated otherwise in a credit line to the material. If material is not included in the article's Creative Commons licence and your intended use is not permitted by statutory regulation or exceeds the permitted use, you will need to obtain permission directly from the copyright holder. To view a copy of this licence, visit http://creativecommons.org/licenses/by/4.0/.

\section{References}

Baddeley, A., Rubak, E., \& Turner, R. (2015). Spatial point patterns: methodology and applications with $R$. Boca Raton, US: Chapman and Hall/CRC.

Barber, M., Field, D., \& Topping, P. (1999). The Neolithic flint mines of England. London: English Heritage. Bevan, A. (2012). Spatial methods for analysing large-scale artefact inventories. Antiquity, 86, 492-506.

Bevan, A. and Crema, E.R. 2018. rcarbon v1.2.0: methods for calibrating and analysing radiocarbon dates URL: https://CRAN.R-project.org/package=rcarbon

Bevan, A., Colledge, S., Fuller, D., Fyfe, R., Shennan, S., \& Stevens, C. (2017). Holocene fluctuations in human population demonstrate repeated links to food production and climate. Proceedings of the National Academy of Sciences Dec 2017, 114(49), E10524-E10531. 
Bradley, R., \& Edmonds, M. (1993). Interpreting the axe trade: production and exchange in Neolithic Britain. Cambridge: Cambridge University Press.

Burton, J. (1989). Repeng and the salt-makers: 'ecological trade' and stone axe production in the Papua New Guinea Highlands. Man, 24, 255-272.

Chao, A., Chiu, C.-H., \& Jost, L. (2014). Unifying species diversity, phylogenetic diversity, functional diversity, and related similarity and differentiation measures through Hill numbers. Annual Review of Ecology, Evolution, and Systematics, 45, 297-324.

Clough, T. H. McK, and W. A Cummins, eds. 1979. Stone axe studies: archaeological, petrological, experimental, and ethnographic. London: Council for British Archaeology.

Clough, T. H. McK, and W. A Cummins, eds. 1988. Stone axe studies volume 2: the petrology of prehistoric stone implements from the British Isles. London: Council for British Archaeology.

Collin, J. P. (2016). Mining for a week or for centuries: variable aims of flint extraction sites in the Mons Basin (province of Hainaut, Belgium) within the lithic economy of the Neolithic. Journal of Lithic Studies, 3(2).

Cooney, G., \& Mandal, S. (1998). Irish stone axe project monograph I. Dublin: Wordwell.

Cooney, G., Warren, G., \& Ballin, T. (2013). Island quarries, island axeheads, and the Neolithic of Ireland and Britain. North American Archaeologist, 34, 409-431.

Cummins, W. A. (1979). Neolithic stone axes: distribution and trade in England and Wales. In Clough, T. H. McK, and W. A Cummins (eds.) Stone axe studies: archaeological, petrological, experimental, and ethnographic (pp. 5-12). London: Council for British Archaeology.

Darvill, T. (1989). The circulation of Neolithic stone and flint axes: a case study from Wales and the mid-west of England. Proceedings of the Prehistoric Society, 55, 41-60.

Darvill, T. (2016). Megalithic tombs, barrows, and enclosures in fourth millennium BC Britain. In V. Ard \& L. Pillot (Eds.), Giants in the landscape: monumentality and territories in the European Neolithic (pp. 317). Oxford: Archaeopress.

Davis, O., \& Sharples, N. (2017). Early Neolithic enclosures in Wales: a review of the evidence in light of recent discoveries at Caerau. The Antiquaries Journal., 97, 1-26.

Davis, R.V., Davis, A.C. and Markham, M. 2009. From implement to outcrop: a model for identifying implement source rock at outcrop using petrological, geochemical, fieldwork and archaeological evidence: a case study of IPG Group XXXIV and Carrock Fell, Cumbria. http://intarch.ac.uk/journal/issue26 /index.htm.

R Development Core Team, 2008. A language and environment for statistical computing. R Foundation for Statistical Computing, Vienna, Austria URL. http://www.R-project.org.

Dijkstra, A. H., \& Hatch, C. (2018). Mapping a hidden terrane boundary in the mantle lithosphere with lamprophyres. Nature Communications, 9, 3770.

Domanski, M., Webb, J. A., Boland, J. (1994). Mechanical properties of stone artefact materials and the effect of heat treatment. Archaeometry 36, 177-208.

Edinborough, K., Porčić, M., Martindale, A., Brown, T. J., Supernant, K., \& Ames, K. M. (2017). Radiocarbon test for demographic events in written and oral history. Proceedings of the National Academy of Sciences, 114(47), 12436-12441.

Edinborough, K., Shennan, S., Teather, A., Baczkowski, J., Bevan, A., Bradley, R., Cook, G., Kerig, T., Parker-Pearson, M., Pope, A., \& Schauer, P. (2019). New radiocarbon dates show Early Neolithic date of flint-mining and stone quarrying in Britain. Radiocarbon. https://doi.org/10.1017/RDC.2019.85.

Evans, J., Rouse, A., \& Sharples, N. (1988). The landscape setting of causewayed camps: some recent work on the Maiden Castle enclosure. In J. Barrett \& I. Kinnes (Eds.), The archaeology of context in the Neolithic and Bronze Age: recent trends (pp. 73-84). Sheffield: J. Collis.

Grimes, W. F. (1979). The history of implement petrology in Britain. In Clough, T. H. McK, and W. A Cummins (eds.) Stone axe studies: archaeological, petrological, experimental, and ethnographic (pp. 14). London: Council for British Archaeology.

Healy, F., Marshall, P., Bayliss, A., Cook, G., Ramsey, C. B., van der Plicht, J., \& Dunbar, E. (2018). When and why? The chronology and context of flint mining at Grime's Graves, Norfolk, England. Proceedings of the Prehistoric Society, 84, 277-301.

Hodder, I. (1974). Regression analysis of some trade and marketing patterns. World Archaeology, 6(2), 172189.

Holgate, R. (1995). Neolithic flint mining in Britain. Archaeologia polona, 33, 133-161.

Kensall, J. E., \& Diggle, P. J. (1995). Non-parametric estimation of spatial variation in relative risk. Statistics in Medicine, 14, 2335-2343.

Markham, M. 2009. The devil is in the detail: a review of Group I and Group III petrographic thin-sections. http://intarch.ac.uk/journal/issue26/index.html 
Markham, M., \& Floyd, P. A. (1998). Geochemical fingerprinting of West Cornish greenstones as an aid to provenancing Neolithic axes. Proceedings. Ussher Society, 9, 218-223.

Mortimore, R. N. (2012). Making sense of chalk: a total-rock approach to its engineering geology. Quarterly Journal of Engineering Geology \& Hydrogeology, 45, 252-334.

Neil, S., Evans, J., Montgomery, J., \& Scarre, C. (2018). Isotopic evidence for landscape use and the role of causewayed enclosures during the earlier Neolithic in southern Britain. Proceedings of the Prehistoric Society, 84, 185-205.

Oswald, A., Dyer, C. and Barber, M. 2001. The creation of monuments: Neolithic causewayed enclosures in the British Isles. London: English Heritage.

Peacock, D. P. S. (1969). Neolithic pottery production in Cornwall. Antiquity, 43, 145-149.

Pétrequin, A.-M., \& Pétrequin, P. (1993). Ecologie D’un Outil : La Hache de Pierre En Irian Jaya (Indonésie). Paris: CNRS éd.

Pétrequin, P., \& Pétrequin, A. M. (2012). Chronologie et organisation de la production dans le massif du Monte Viso. Pétrequin, P., S. Cassen, M. Errera, L. Klassen, J. A. Sheridan, and A.-M. Pétrequin. Jade. Grandes Haches Alpines Du Néolithique Européen. Ve et IVe Millénaires Av. J.-C., pp. 214-257. Besançon: Presses Universitaires de Franche-Comté.

Pioffet, H., 2014. Sociétés et identités du premier néolithique de Grande-Bretagne et d'Irlande: caractérisation et analyses comparatives des productions céramiques entre Manche, Mer d'Irlande et Mer du Nord (Doctoral dissertation, Rennes 1).

Pitts, M., 1996. The stone axe in Neolithic Britain. In Proceedings of the Prehistoric Society 62: 311-371. Cambridge University Press.

Renfrew, C. (1975). Trade as action at a distance. In J. Sabloff \& C. C. Lamberg-Karlovsky (Eds.), Ancient civilisation and trade: 3-60. Tuscon: University of Arizona Press.

Renfrew, C. (1977). Alternative models for exchange and spatial distribution. In T. K. Earle \& J. E. Ericson (Eds.), Exchanges systems in prehistory (pp. 71-90). London: Academic Press.

Richards, J. A. (2013). Remote sensing digital image analysis - An Introduction. Berlin: Springer.

Risch, R. (2011). Social and economic organisation of stone axe production and distribution in the western Mediterranean. In R. V. Davis \& M. Edmonds (Eds.), Stone axe studies III (pp. 99-118). Oxford: Oxbow.

Roe, F. 1968. Stone mace-heads and the latest Neolithic cultures of the British Isles. In Coles, JM and Simpson, DDA. (eds), Studies in ancient Europe: essays presented to Stuart Piggott. Leicester University Press, 145-172.

Roe, F. (1979). Typology of stone implements with shaftholes. In Clough, T. H. McK, and W. A Cummins (eds.) Stone axe studies: archaeological, petrological, experimental, and ethnographic (pp. 23-48). London: Council for British Archaeology.

Schauer, P., Shennan, S., Bevan, A., Cook, G., Edinborough, K., Fyfe, R., Kerig, T., \& Pearson, M. P. (2019). Supply and demand in prehistory? Economics of Neolithic mining in northwest Europe. Journal of Anthropological Archaeology, 54, 149-160.

Shennan, S., 1997. Quantifying archaeology. University of Iowa Press.

Sheridan, J. A. (2010). The Neolithization of Britain and Ireland: the 'big picture'. In B. Finlayson \& G. Warren (Eds.), Landscapes in transition (pp. 89-105). Oxford: Oxbow.

Sheridan, J A \& Pailler, Y. 2012. Les haches alpines et leurs imitations en Grande-Bretagne, dans l'Île de Man, en Irlande et dans les îles Anglo-Normandes. In S. Cassen, M. Errera, L. Klassen, A. Sheridan and A.M. Pétrequin (eds), JADE. Grandes haches alpines du Néolithique européen. Ve et IVe millénaires av. J.-C. Cahiers de la MSHE C.N. Ledoux, Besançon, Presses Universitaires de Franche-Comté et Centre de Recherche Archéologique de la Vallée de l'Ain, Vol. 2: 1046-1087.

Simpson, E. H. (1949). Measurement of diversity. Nature, 163, 688.

Smith, I. F. (1971). Causewayed enclosures. In D. Simpson (Ed.), Settlement and economy in Neolithic and Early Bronze Age Britain and Europe (pp. 89-112). Leicester: Leicester University Press.

Smith, IF. 1979 The chronology of British stone implements. In Clough, T. H. McK., and W. A. Cummins (eds.) Stone axe studies: archaeological, petrological, experimental, and ethnographic, 13-22. London: Council for British Archaeology.

Smith, B. A., Davies, T. M., \& Higham, C. F. W. (2015). Spatial and social variables in the Bronze Age Phase 4 cemetery of Ban NonWat. Northeast Thailand, Journal of Archaeological Science: Reports, 4, 362370.

Tallavaara, M., Pesonen, P., Oinonen, M., \& Seppä, H., 2014. The mere possibility of biases does not invalidate archaeological population proxies-response to Teemu Mökkönen. Fennoscandia Archaeologica XXXI, 135-140.

Taylor, S. (2017). Journeys to Neolithic Langdale: how a Cumbrian landscape may help explain prehistoric movement of polished stone axes. Lithics-The Journal of the Lithic Studies Society, 37, 15. 
Timpson, A., Colledge, S., Crema, E., Edinborough, K., Kerig, T., Manning, K., Thomas, M. G., \& Shennan, S. (2014). Reconstructing regional demographies of the European Neolithic using radiocarbon dates: a new case-study using an improved method. Journal of Archaeological Science, 52, 549-557.

Timpson, A., Manning, K., \& Shennan, S. (2015). Inferential mistakes in population proxies: a response to Torfing's "Neolithic population and summed probability distribution of 14C-dates". Journal of Archaeological Science, 63, 199-202.

Topping, P. 2019. The social context of lithic extraction in Neolithic Britain and Ireland. In A Teather, P Topping \& J Baczowski (eds), Mining and quarrying in Neolithic Europe: a social perspective. Oxbow.

Whittle, A. W. R., Healy, F., \& Bayliss, A. (2011). Gathering time: dating the early Neolithic enclosures of southern Britain and Ireland. Oxford: Oxbow.

Woodbridge, J., Fyfe, R. M., Roberts, N., Downey, S., Edinborough, K., \& Shennan, S. (2014). The impact of the Neolithic agricultural transition in Britain: a comparison of pollen-based land-cover and archaeological 14C date-inferred population change. Journal of Archaeological Science, 51, 216-224.

Publisher's Note Springer Nature remains neutral with regard to jurisdictional claims in published maps and institutional affiliations.

\section{Affiliations}

\section{Peter Schauer ${ }^{1}$ - Andrew Bevan ${ }^{1}$. Stephen Shennan ${ }^{1} \cdot$ Kevan Edinborough ${ }^{2}$. Tim Kerig ${ }^{3} \cdot$ Mike Parker Pearson $^{1}$}

Peter Schauer

p.schauer@ucl.ac.uk

Andrew Bevan

a.bevan@ucl.ac.uk

Kevan Edinborough

kevan.edinborough@unimelb.edu.au

Tim Kerig

tim.kerig@uni-leipzig.de

Mike Parker Pearson

m.parker-pearson@ucl.ac.uk

1 UCL Institute of Archaeology, 31-34 Gordon Square, London WC1H 0PY, UK

2 University of Melbourne, Melbourne, Australia

3 Universität Leipzig, Leipzig, Germany 